\title{
Fertcel-Clinoptilolite Natural Product to Optimize the Fertilization and Reduce Environmental Pollution
}

\author{
Jorge Alberto Febles González ${ }^{1}$, Fernando Borsatto Faria ${ }^{1}$ and Miguel Soca Nuñez ${ }^{2}$ \\ 1. Technical Department, Indústrias Celta Brasil Ltda, Cotia 06705-150, São Paulo, Brasil \\ 2. Soil Institute, Ministry of Agriculture, Highway Costa-Costa, Boyeros 10800, La Habana, Cuba
}

\begin{abstract}
The shortages of chemical fertilizers in Cuba in 90s caused the introduction of different research results obtained on this time for the implementation of natural zeolites in the fertilizer industry. It's known as the high capacity of cation exchange of the natural Cuban clinoptilolite, which contributes to reducing nutrient losses, such as ammonia, and keeping the potassium and phosphorus cations available. Extensive tests were done on the field with the objective to evaluate the agronomic effect of incorporating this mineral in fertilizer. The results obtained in this experiment contributed to almost all Cuban chemical fertilizers, which has been incorporated around 15\%-20\% of natural zeolite clinoptilolite in its composition by Cuban agriculture consumes, reducing the chemical carriers of the fertilizers and decreasing the contamination of the environment. Also this mineral contributes for increases in agricultural income more than $15 \%$ in all cases; additionally, a trend can be observed towards gradual recovery of some soil fertility indicators, in which the chemical fertilizers with Fertcel was applied.
\end{abstract}

Key words: Zeolite clinoptilolite, fertilization, agriculture, environmental pollution, Fertcel.

\section{Introduction}

Modern agriculture uses fertilizers with high concentration of nutrients, which have high solubility. It is predominantly accepted that the repeated application of these fertilizers can bring long-term adverse impacts on the soil and environment [1].

An interesting alternative would be to consider the availability of a renewable fertilizer with controlled release, which can ensure high crop yields with lower dosages of nutrients and meanwhile the soil fertility is not affected [2]. Because of this, it was decided to carry out the evaluation of a new type of fertilizer-inclusion of natural zeolite (clinoptilolite) in the NPK fertilizer. This new fertilizer might enable nutrient release in a controlled manner, decreases the dosing of nutrients in crops without affecting yields and soil properties [3, 4], thus can avoid some negative environmental consequences associated with high concentration of chemical fertilization, nutrient

Corresponding author: Jorge Alberto Febles González, Ph.D., research field: soil conservation and improvement. E-mail: febles@celtabrasil.com.br. solubility and make a more sustainable agriculture [5]. In composition, zeolites are similar to clay minerals; more specifically, both are aluminum silicates. They differ, however, in their crystalline structure. Many types of clay have a layered crystalline structure (similar to a deck of cards) and are subject to shrinking and swelling as water is absorbed and removed between the layers [6]. In contrast, zeolites have a rigid, 3-dimensional crystalline structure (similar to a honeycomb) consisting of a network of interconnected tunnels and cages. The net negative charge within the voids holds the cations for the cation exchange capacity (CEC). The open and negatively charged framework results in zeolite's ability to exchange plant nutrients inside and outside of the stable three dimensional honeycomb framework [7, 8].

For this purpose, it was used the Cuban natural zeolite with over $98 \%$ of clinoptilolite in its composition, which showed that introducing this mixture to chemical fertilizers reduces adding inputs by up to $25 \%$ by increasing efficiency thereof and improving soil fertility. 
This research aimed to evaluate the efficiency of NPK fertilizers with the incorporation of $25 \%$ of zeolite clinoptilolite from Tasajeras deposit for different crops.

\section{Materials and Methods}

The mineralogical composition of the zeolite used is $98 \%$ clinoptilolite and $2 \%$ mordenite from Tasajeras deposit of the central region of Cuba, and is analyzed by X-ray diffraction (Xpert Pro/Panalytical) technique, with an average chemical composition present in Table 1 . The sample of this mineral was analyzed by X-ray fluorescence (XRF-1800/Shimadzu) technique.

An equally important aspect of this mineral is the physical characteristics (Table 2). It has a high pore volume, which gives the mineral a large area of absorption and ion exchange and allows moisture retention higher than 40\%, like potassium and ammonium (these elements are available to crops).

From the participation of simple chemical carriers, the recommended formulations of ammonium sulfate (20.6-0-0), simple superphosphate (0-19.5-0) and potassium chloride (0-0-60) were developed for different crops, which were compared to those incorporated with $25 \%$ clinoptilolite type zeolite with a grain size of 1-3 mm. Replacing the same percentage to all carriers, NPK formulations in this way was corroborated in field studies to product the positive results obtained in another series of experiments at controlled scale.

The soil where the experiments were conducted are classified as Ferralític red dark [9], which corresponded to a Rhodic Eutrusteox deep [10], flat topography, low organic matter content (2\%), CEC of 13-26 meq/100 g soil, $\mathrm{pH}$ less than 6 , found in the Southwestern plains of Cuba.

\section{Results and Discussion}

Adding 25\% of natural zeolite to NPK fertilizer, although lowered NPK nutrients provided by the formula, increased crop yields $37.98 \%$ on average by evaluating different crops in Table 3. This demonstrates the efficiency of natural zeolite in retention of nutrients that were provided by chemical fertilizers, because high capacity cation exchange of this mineral compared to the soil (157 meq/100 g zeolite vs. $26 \mathrm{meq} / 100 \mathrm{~g}$ soil) allows to increase nutrient retention by more than five times, which can act as a storehouse of nutrients available to crops. Traditional conditions of application of NPK fertilizer supply more cations to soil than its holding capacity, causing leaching or volatilization of nitrogen carriers.

In mineral fertilizers NPK with $25 \%$ zeolite, the efficiency of utilization of nutrients is $44.42 \%$ compared to the traditional average; maize shows the largest increases in efficiency of utilization of fertilization (60.83\%), mainly because this crop is highly demanding of nutrients, primarily nitrogen, which the natural zeolite retains interchangeably and is

Table 1 Average chemical composition of natural zeolite deposit Tasajeras, Cuba.

\begin{tabular}{llllllllllll}
\hline \multicolumn{10}{c}{ Percentage } \\
\hline $\mathrm{SiO}_{2}$ & $\mathrm{Al}_{2} \mathrm{O}_{3}$ & $\mathrm{CaO}$ & $\mathrm{Na}_{2} \mathrm{O}$ & $\mathrm{Fe}_{2} \mathrm{O}_{3}$ & $\mathrm{FeO}$ & $\mathrm{K}_{2} \mathrm{O}$ & $\mathrm{TiO}_{2}$ & $\mathrm{MgO}$ & $\mathrm{P}_{2} \mathrm{O}_{5}$ & $\mathrm{O}$ ther & $\mathrm{pH}$ \\
\hline 74.01 & 11.56 & 5.10 & 2.45 & 2.62 & 0.81 & 1.89 & 0.44 & 0.65 & 0.08 & $<1.00$ & 7.6 \\
\hline
\end{tabular}

Source: descriptive leaflet zeolite clinoptilolite, Indústrias Celta Brazil (www.celtabrasil.com.br).

Table 2 Physical characteristics of natural zeolite deposit Tasajeras, Cuba.

\begin{tabular}{ll}
\hline Physical characteristics & Value \\
\hline Bulk density & $0.98 \mathrm{~g} / \mathrm{L}$ \\
Surface area & $40 \mathrm{~m}^{2} / \mathrm{g}$ \\
Pore volume & $51.1 \%$ \\
Cation exchange capacity & $1.57 \mathrm{mg} / \mathrm{g}$ \\
\hline
\end{tabular}

Source: descriptive leaflet of zeolite clinoptilolite, Indústrias Celta Brazil (www.celtabrasil.com.br). 
Table 3 Comparison of the efficiency of fertilizer incorporation of $25 \%$ of clinoptilolite.

\begin{tabular}{|c|c|c|c|c|c|c|c|}
\hline Crops & Formula & $\begin{array}{l}\text { Doses } \\
(\mathrm{kg} / \mathrm{ha})\end{array}$ & $\begin{array}{l}\text { NPK } \\
(\mathrm{kg} / \mathrm{ha})\end{array}$ & $\begin{array}{l}\begin{array}{l}\text { Yield } \\
\text { (ton/ha) }\end{array} \\
\end{array}$ & $\begin{array}{l}\text { Increment } \\
(\%)\end{array}$ & $\begin{array}{l}\text { NPK (kg/tons of } \\
\text { production) }\end{array}$ & $\begin{array}{l}\text { NPK efficiency } \\
\text { (\%) }\end{array}$ \\
\hline \multirow{2}{*}{ Potato } & $10-17-24$ & 1,490 & 759.90 & 24.31 & & 31.26 & \\
\hline & 9-13-17 & 1,490 & 581.10 & 29.46 & 21.2 & 19.73 & 36.88 \\
\hline \multirow{2}{*}{ Corn } & 8-9-14 & 550 & 170.50 & 3.15 & & 54.13 & \\
\hline & $6-7-10$ & 550 & 129.25 & 6.10 & 93.7 & 21.20 & 60.83 \\
\hline \multirow{2}{*}{ Bean } & $9.5-9.5-9.5$ & 745 & 212.32 & 1.29 & & 164.59 & \\
\hline & $7-7-7$ & 745 & 156.45 & 1.50 & 17.0 & 104.30 & 36.63 \\
\hline \multirow{2}{*}{ Tomato } & 9.5-9.5-9.5 & 730 & 208.10 & 25.50 & & 8.25 & \\
\hline & $7-7-7$ & 730 & 153.30 & 35.19 & 38.0 & 4.31 & 47.75 \\
\hline \multirow{2}{*}{ Cucumber } & 8-9-14 & 780 & 241.60 & 32.40 & & 7.46 & \\
\hline & $6-7-10$ & 780 & 179.40 & 43.60 & 35.0 & 4.11 & 44.90 \\
\hline \multirow{2}{*}{ Sweet potato } & $8-9-14$ & 620 & 192.20 & 11.50 & & 16.71 & \\
\hline & $6-7-10$ & 620 & 142.60 & 14.20 & 23.0 & 10.04 & 39.50 \\
\hline Average & & & & & 37.98 & & 44.42 \\
\hline
\end{tabular}

Table 4 Results of soil $(0-20 \mathrm{~cm})$ with fertilizer with $25 \%$ of clinoptilolite.

\begin{tabular}{|c|c|c|c|c|c|c|c|c|c|}
\hline \multirow[t]{2}{*}{ Crops } & \multirow[t]{2}{*}{ Variant } & \multirow[t]{2}{*}{$\mathrm{pH}$} & \multicolumn{4}{|c|}{$\begin{array}{l}\text { Exchangeable cations concentration } \\
\text { (mmol/100 g of soil) }\end{array}$} & \multirow[t]{2}{*}{ CEC } & \multicolumn{2}{|c|}{$\begin{array}{l}\text { Assimilable cations } \\
\text { (mg/100 g of soil) }\end{array}$} \\
\hline & & & $\overline{\mathrm{Ca}^{+2}}$ & $\mathrm{Mg}^{+2}$ & $\mathrm{~K}^{+}$ & $\mathrm{Na}^{+}$ & & $\mathrm{P}_{2} \mathrm{O}_{5}$ & $\mathrm{~K}_{2} \mathrm{O}$ \\
\hline \multirow{3}{*}{ Potato } & 0 & 6.70 & 14.21 & 2.37 & 0.67 & 0.09 & 17.34 & 4.12 & 9.42 \\
\hline & $10-17-24^{*}$ & 6.70 & 14.21 & 2.49 & 0.67 & 0.09 & 17.46 & 8.41 & 13.10 \\
\hline & $9-13-17 * *$ & 6.80 & 14.82 & 2.63 & 0.73 & 0.09 & 18.27 & 9.62 & 15.12 \\
\hline \multirow{3}{*}{ Corn } & 0 & 5.10 & 8.20 & 1.63 & 0.76 & 0.09 & 10.68 & 7.80 & 13.30 \\
\hline & $8-9-14 *$ & 5.20 & 8.10 & 1.69 & 0.82 & 0.09 & 10.70 & 10.30 & 15.90 \\
\hline & $6.5-7-10 * *$ & 5.20 & 8.30 & 1.69 & 0.91 & 0.15 & 11.05 & 16.40 & 17.80 \\
\hline \multirow{3}{*}{ Bean } & 0 & 4.60 & 7.00 & 1.40 & 0.26 & 0.10 & 8.76 & 4.70 & 6.70 \\
\hline & $9.5-9.5-9.5 *$ & 4.60 & 7.00 & 1.50 & 0.31 & 0.10 & 8.91 & 7.50 & 12.25 \\
\hline & $7-7-7 * *$ & 4.80 & 7.10 & 1.70 & 0.35 & 0.15 & 9.30 & 10.40 & 17.50 \\
\hline \multirow{3}{*}{ Tomato } & 0 & 5.10 & 8.20 & 2.27 & 0.30 & 0.10 & 10.87 & 4.10 & 9.75 \\
\hline & 9.5-9.5-9.5* & 5.10 & 8.70 & 2.23 & 0.32 & 0.10 & 11.35 & 6.25 & 12.25 \\
\hline & $7-7-7 * *$ & 5.30 & 9.10 & 2.43 & 0.37 & 0.15 & 12.05 & 8.80 & 15.22 \\
\hline \multirow{3}{*}{ Cucumber } & 0 & 5.50 & 10.70 & 8.10 & 0.60 & 0.10 & 19.50 & 3.75 & 11.75 \\
\hline & $8-9-14 *$ & 5.50 & 10.70 & 8.30 & 0.50 & 0.10 & 19.60 & 6.65 & 13.75 \\
\hline & $6-7-10 * *$ & 5.60 & 11.90 & 8.90 & 0.75 & 0.25 & 21.80 & 9.75 & 15.90 \\
\hline \multirow{3}{*}{ Sweet potato } & 0 & 4.30 & 3.00 & 1.60 & 0.50 & 0.10 & 5.20 & 4.75 & 8.15 \\
\hline & $8-9-14 *$ & 4.40 & 2.90 & 1.60 & 0.50 & 0.10 & 5.10 & 6.25 & 10.15 \\
\hline & $6-7-10^{* *}$ & 4.90 & 4.10 & 2.20 & 0.70 & 0.15 & 7.15 & 12.15 & 16.75 \\
\hline
\end{tabular}

*without clinoptilolite; **with $25 \%$ of clinoptilolite.

available for crops. It coincides with the report of Refs.

[11-13] that using natural zeolite in agriculture has the possibility of saving mineral fertilizers and thus reduces the negative impact on the environment.

When analyzing the results of soil $(0-20 \mathrm{~cm}$ depth) in different crops with fertilizer application with $25 \%$ zeolites (Table 4), large differences are observed in the content of the exchangeable cations or $\mathrm{pH}$.
Although there is a tendency to increase the soil's total CEC regarding the NPK application, the increase in sweet potatoes reached $40 \%$, whereas in maize cultivation this increase was $3.27 \%$. While, the contents of $\mathrm{P}_{2} \mathrm{O}_{5}$ and $\mathrm{K}_{2} \mathrm{O}$ increased significantly to $94.4 \%$ and $65.02 \%$, respectively, in the cultivation of sweet potato. By the incorporation of natural clinoptilolite, it indicates the ability to not only make 
crop nutrition more efficient but also allow the gradual recovery of fertility of degraded soil through the continued and systematic use of fertilizers with this valuable mineral.

\section{Conclusions}

The inclusion of $25 \%$ natural clinoptilolite in the chemical fertilizers significantly improved the efficiency of fertilization, increased crop yields and reduced nutrient formulas, allowing us to develop a more ecological and sustainable agriculture.

A tendency was observed to increase the values of $\mathrm{Ca}^{2+}, \mathrm{P}_{2} \mathrm{O}_{5}, \mathrm{~K}_{2} \mathrm{O}$ and $\mathrm{CEC}$ in soil where chemical fertilizers were applied with natural clinoptilolite, allowing the gradual recovery from soil fertility.

The authors recommend the inclusion of $25 \%$ clinoptilolite zeolites type in the formulations of chemical fertilizers NPK, because it contributes to achieving good crop yields and simultaneously minimizing negative effects on the environment caused by fertilization.

\section{References}

[1] Soca, M., Castellanos, J., and Febles, J. 2004. "Effect of Zeolite in Efficiency of Chemical Fertilizers, Fertilizers and Mineral Amendments.” Panorama Minero Journal 14: 261-8. (in Spanish)

[2] Lewis, M. D., Moore, F. D., and Goldberry, K. L. 1984. "Ammonium-Exchanged Clinoptilolite and Granulated Clinoptilolie with Urea as Nitrogen Fertilizers.” In Zeo-Agriculture: Use of Natural Zeolites in Agriculture and Aquaculture, edited by Pond, W. G., and Mumptom, F. A. Boulder, CO, USA: Westview Press, 264.

[3] MacKown, C., and Tucker, T. 1985. "Ammonium Nitrogen Movement in a Coarse-Textured Soil Amended with Zeolite.” Soil Science Society of America Journal 49 (1): 235-8.

[4] Allen, E. R., Hossner, L., Ming, D., and Henninger, D. 1996. "Release Rates of Phosphorus, Ammonium and Potassium in Clinoptilolite-Phosphate Rock Systems." Soil Science Society of America Journal 60 (5): 1467-72.

[5] Ferguson, G., and Pepper, I. 1987. "Ammonium Retention in Sand Amended with Clinoptilolite.” Soil Sciences Society of American Journal 51 (1): 231-4.

[6] ZeoponiX Inc. and Boulder Innovative Technologies Inc.. 2000. “Zeolite: The Versatile Mineral.” Accessed March 2015. http://www.zeoponix.com/zeolite.htm.

[7] Breck, D. W. 1974. Zeolite Molecular Sieves, Structure, Chemistry and Use. New York: John Wiley and Sons, 771.

[8] Holmes, D. A. 1994. "Zeolites.” In Industrial Minerals and Rocks, 6th ed., edited by Carr, D. D. Littleton, Colorado: Society for Mining, Metallurgy and Exploration Inc., 1129-58.

[9] Soil Institute. 1994. Genetic Classification of Soils of Cuba, 4th ed.. Havana, Cuba: Ministry of Agriculture, 36. (in Spanish)

[10] United States Department of Agriculture (USDA). 1994. Keys to Soils Taxonomy, 3rd ed.. USA: Soils Conservation Service, 305.

[11] Soca, M., Febles, J., and Arias, E. 1991. "Using Natural Zeolites in Different Soils and Crops as a Way to Increase the Efficiency of Mineral Fertilizers." In Proceedings of the 3rd International Conference on the Occurrence, Properties and Utilization of Natural Zeolites, 126.

[12] Febles, J., and Velazquez, M. 2006. “Agricultural Results Obtained in the Use of Cuban Zeolites in Some Latin American Countries.” In Proceedings of 7th International Conference on Occurrence, Properties and Utilization of Natural Zeolites, 108.

[13] Vasquez-Hernández, A., and Meneses, I. 2010. Use of Zeolites to Increase the Efficiency of Chemical Fertilizers Applied to Corn in Veracruz. Agro Magazine Environment Report, Veracruz. 